\title{
ISOLATION AND IDENTIFICATION ON DEGRADATOR BACTERIUM OF PETROLEUM WASTE WHICH SYMBIONS WITH SPONGE FROM MELAWAI BEACH
}

\author{
Ismail Marzuki ${ }^{*}$, Alfian Noor ${ }^{2}$, Nursiah La Nafie ${ }^{3}$, M. Natsir Djide ${ }^{4}$ \\ ${ }^{1,2,3}$ Department of Chemistry, Faculty of Mathematics and Natural Sciences, Hasanuddin \\ University \\ ${ }^{4}$ Department of Pharmacy, Faculty of Pharmacy, Hasanuddin University \\ *E-mail: ismailmz3773@gmail.com
}

\begin{abstract}
The research has been done about isolation and identification on degradator bacterium of petroleum waste which symbions with sponge from Melawai Beach, Balikpapan. The research objectives; knowing sponge species, symbioning bacterium isolate and its ability of petroleum waste degradation. The research method were analysis of sponge Morphology analysis, isolation of symbions bacterium, identification, and activity testing at petroleum waste media which is coming from wells result of processing of PT. Chevron. The research result obtained the morphology analysis concluded that the sponges is Callyspongia sp. Bacterium symbion isolation obtained that two isolates which were given each symbols isolate A with the rounded shape and crem color whereas isolate B with yellow color and jagged shape. Coloring analysis of isolate obtained that isolate A is negative gram bacterium type and isolate B is positive gram bacterium type. Activity isolate testing at petroleum waste media, isolate A did not grow significantly at the media which marked with the existence of layer transparent on the media, isolate B growth significantly which marked with existence of solidity on the media, and the combination of isolate $\mathrm{A}+\mathrm{B}$ also showed growth which marked with the existence of layer transparent and solidity on media. The conclusions research, sponge species is Callyspongia sp which contained two isolates bacterium namely negative gram bacterium and positive gram bacterium and both of the isolates can grow at media of petroleum waste.
\end{abstract}

Key word: sponge, symbion, bacterial, degradation, petroleum waste 


\section{INTRODUCTION}

Environmental role of human life deep sea very of vital, not merely as transfortation medium, more than that sea represent assorted life place of biota and required to guarantee the continuity of being life is including human being. Besides at sea often found by minerals deposit, gas and petroleum which also very of vital for the human of life. Technological growth and make-up of requirement of human being force for the exploitation of is environmental of sea with exploitation and exploration various properties in it. As a result generate problems which actually earn life threatening and continuity of being life live not merely biota exist in depth but also itself human life.

Melawai Beach of Balikpapan is including one of the destination tourism and culinery visited by many people not merely simply see evening sundown but also as medium to enjoy 2 the coastal island which namely Island Twin of Tukung. Melawai Beach also represent place fisherman of boat it and place pamper eye seen oil tanker transfortation, mercantile marine and Pelni ship which by pass quickly, this situation happened every day which give contribution is make-up of petroleum volume which castaway in sea. This research target identifying spons and bacterium its Melawai Beach of Balikpapan, East Kalimantan as impure area of expected petroleum waste finding of sponge type and symbioning bacterium which can petroleum waste decomposed. This research contribution is to assist government in identifying sponge type and simbion bacterium which can decompose petroleum waste so that affect petroleum waste negative to damage of sea biota earn minimization.

\section{THEORY}

Melawai Beach up at distance around $1.500 \mathrm{~m}$ there are Refinery Balikpapan operating since year 1973 and $700 \mathrm{~m}$. There are port of Semayang and also part of east there are Hospital Pertamina growing is vital of this Melawai Beach at the same time as source of contamination of heavy metal and petroleum waste which can menace life of being live the including human being and biota in it. Uniqly of differ from Melawai Beach is there are sea biota life owning big enough benefit, namely sponge ${ }^{[14,19]}$.

Research about heavy metal contamination like lead, copper, merkuri and arsenic at Melawai Beach of Balikpapan caused by many petroleum poured out from refinery activity, sea transfortation, port actifity, wash of hospital activity ship as well as human being activity ${ }^{[14]}$.

Poured out petroleum effect not merely at damage influence of coastal esthetics nya, however also have an in with annoyed of life of biota go out to sea exist in depth which is on finally affect negativity at human life the core important which is many have interaction to with the Melawai beach ${ }^{[11]}$.

Indonesia having spons type megadivercity, and often found by have symbiosis with microorganisme. Sponge is animals have pore to having the character of feeder filter so that become habitat to microorganisme to have a nest in its body. Microorganisme have two important role in biological system of sponge, that is first as source of food and both life have symbiosis to either through inter and also intra cellular, ${ }^{[3,6,22]}$. Some found by sponge type is symbiosis with bacterium, like: Spons Theonella sp,, Surassinoru Melophlus, Callyspongia sp, Ircinia sp, 
Stylissa Blabeli, Lisoclinum sp, Clathria sp, Jaspis sp, P. nigra, X.Testudinaria and stellifera, ${ }^{[13,15,20]}$.

Some microorganisme sea (bacterium) known can aromatik hydrocarbon compound degradator with high toksisity for example: Pseudomonas, Arthrobacter, Alcaligenes, Brevibacterium, Brevibacillus, and Bacillus, ${ }^{[2,7,21]}$. Faction aromatik compound component degradator by bacterium, for example: Macerans Bacillus, $B$. mycoides, B. megaterium, B. subtilis, B. pumilus, B. thermoleovorans, B. gordonae, and B. benzoevorans $\left[18,{ }^{24]}\right.$, Enterobacter., Bacillus sp., Clastiridium Sp., Arthobacter sp., Shigella sp., Pseudomonas sp., Aeromonas sp., and Citrobacter sp., [4], and most of the bacterium can symbioning with sea spons ${ }^{[15]}$.

The importance of assorted explorasi of bacterium which can PAH degradation, considering the nature of very toxic PAH, mutagenic and is carcinogenic, at the same time this petroleum waste besides pregnant many PAH compound also it contains some kinds of heavy metal which have potency add impure storey level of environmental of sea, and also process its decomposition need sufficient time ${ }^{[1,5,16]}$.

This research include to identify sponge type which is life at impure area of petroleum waste, simbion isolate bacterium, and activity test growth of symbion bacterium isolat at petroleum waste media. To reach the the target hence conducted by some model namely analyse sponge morphology, symbion isolate bacterium of one of the anticipated by sponge type is simbioning with bacterium which can hydrocarbon decompesed, symbion bacterium isolate gram analysis through analysis and coloration growth of symbion isolate at petroleum waste media.

\section{MATERIAL AND METHOD}

\section{Materials}

Sampel Sponge, $\mathrm{CH}_{3} \mathrm{OH}$ p.a., sterile Water Sea, Phospat Buffer Saline (PBS), Sea Water Complit (SWC), marine so that, gliserol 25\%, bacterium isolate, petroleum waste, $\mathrm{NaCl}$ 0,9\%, formalin 4\%, Aqubides, aquades, MTT reagen, DMSO.

\section{Appliance}

Scuba, camera in water, GPS, Balance (dissectingpan), scalpel, forceps, pial (toples), plastic sack;bag, ice box, Set microscope, Porcelain cup, pestle and lumpang, chemical glass, measure glass, volume pipette, drip pipette, Erlenmeyer, analytic balance, plate hot, funnel, rubber suck, electrics waterbath, whatman paper, oven, freezer, BOD bottle, water thermometer, universal paper, salinometer, save reaction, solder cup, sentrifugasi $1000 \mathrm{rpm}$ and $4 \mathrm{rpm}$, stop watch, vortex, laminary irrigate flow, tail ose, prevarat glass, autoclove, NA media, filter $0,2 \mu \mathrm{m}$, blender, haemositometer

\section{Place and Research Time}

Research time executed in May to September, 2014. Research place at Microbiological Laboratory of Pharmacy, Faculty of Pharmacy, Universitas of Hasanuddin, and Laboratory Ecology ITS

\section{Sampel and Location Sampling}

Intake of potential Sampel sponge done by 4 dot differ at Melawai Beach of Balikpapan, at deepness 2-7 m with diving scuba technique executed on 19 December 2013. After lifted from sea level, is immediately conducted by 
photograph and taken by some of its networking, is later; then entered into medium $5 \%$ broth marine for the isolation of its bacterium way of (plating direct).

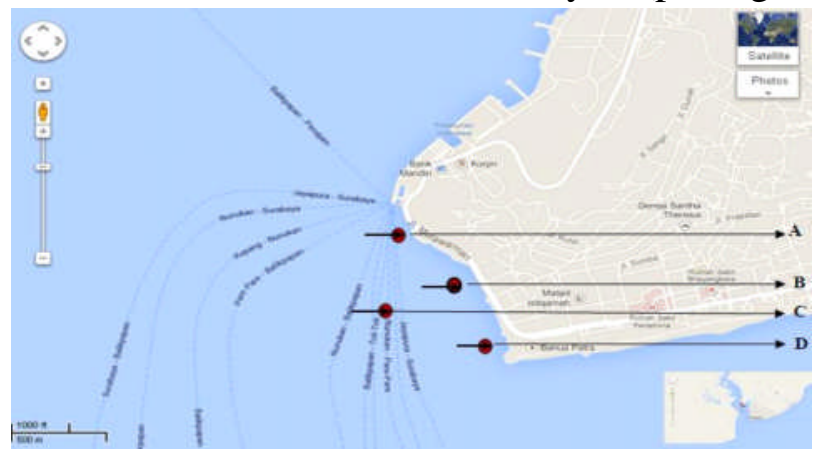

Figure 1: Dot A : Code Sampel 1; Dot B : Code Sampel 2; Dot C : Code Sampel 3; Dot D : Code Sampel 4

Identify spons done by noting special marking (colour, tekstur, form, size measure and deepness) intake moment. Later; Then systematic way and identify sponge morphology follow guide-book ${ }^{[9]}$.

Sponge sampel taken by four dot with code of sample A, B, C, and D successively as sampel 1, 2, 3, and 4. Sample sponge sea taken by at impure area of petroleum sludge hydrocarbon waste around Melawai Beach, Balikpapan, East Kalimantan at deepness 2-7 $\mathrm{m}$ with diving technique (according to condition), is then entered into sterile plastic sack, bag of dark chromatic, is later then kept in box ice and brought to Laboratory to be analysed. Measured supporter data in each sampling dot coordinate point, temperature, deepness, salinity, and $\mathrm{pH}$.

\section{Analysis Method}

Method of analysis conducted in 5 (five) work step: 1) spons morphology analysis; 2) Callyspongia sp spons symbions bacterium isolation; 3) purification of isolate; 4) Identify perception and bacterium microscopicly; and 5) test growth of bacterium at media of petroleum waste.

\section{Analysis Morphology sponge}

Cell of morphology below MTT method inverted microscope, assay, (A) Culture Cell Before Treatment of inkubasi 24 clock, after 4 hour addition of MTT reagen, (B) Control cell, (C) concentration extract $960 \mu \mathrm{g} / \mathrm{mL}$, (D) concentration extract 7,5 $\mu \mathrm{g} / \mathrm{mL}$, (E) control DMSO. Analysis Morphology spons to know gender and its species is done in Laboratory ITS ecology, Surabaya.

\section{Bacterium sponge symbion isolation}

Sponge go out to sea sampel code 1 (deepness 2,7 m), Callyspongia sp species which have been taken to be sprayed at part of surface with sterile sea water with sponge size measure comparison $1 \mathrm{~cm}^{2}: 5$ sterile sea water $\mathrm{mL}$, so that only bacterium with energy join just strong to sampling. Part of mesohyl taken of the size $\pm 1 \times 1 \mathrm{~cm}$, is attenuated and thinned with Phospat Buffer Saline (Sterile PBS) with comparison 1:1 ${ }^{[12]}$. Isolation of bacterium from surface outside use sterile swab ${ }^{[23]}$, which is stroked one wayly at external surface of spons. Sterile Swab which have been stroked by at surface of sampel entered into containing thinning tube of Sterile PBS and the vorteks

Result of thinning disseminated into solder cup which have contained Sea Water Complit media (SWC) with composition 1 media litre consist of $5 \mathrm{~g} / \mathrm{L}$ Bacto 
pepton, $1 \mathrm{~g} / \mathrm{L}$ Yeast extract, and $3 \mathrm{~mL} / \mathrm{L}$ Glycerol, and the inkubacition at temperature $26^{\circ} \mathrm{C}$ during 24-36 clock, perceived by growth of its bacterium colony. Each; every bacterium colony which grow to be perceived its his, namely colour, size measure and colony form, is and also purified by using is same of media.

\section{Purification of Bacterium Symbions}

At plating direct the method moment in field, perceived by colony which grow after incubacy during one till two week. To the number of colony counted, later; then colony which is form and its colour differed isolation. Each colony done by purification, that is by inscribing 1 colony ose instruct zig-zag at containing solder cup of media 100\% marine-agar so thatlater; then the incubations at temperature $30^{\circ} \mathrm{C}$ during 1-2 day. After growing, colony just conducted by incision repeat at media $100 \%$ marine-agar is till got by single colony.

Rich method done with spreading of culture dilution to media $100 \%$ marineagar to be, done by after incubations two week, hereinafter like plating direct method, incubaced ulture at temperature $30^{\circ} \mathrm{C}$ during one colony amount and week counted, dipurifikasi and isolation. Result depository of purification use $25 \%$ gliserol in media marine-agar.

\section{Identify and perception isolate bacterium in microscopicly}

Process identify to cover coloration of gram, with intake of bacterium breeding 1 ose at previous glass object have is free of fat with alcohol $96 \%$, then in violet crystal dropped (Gram A) 1-3 drip made by hapused, hushed is later;then cleaned to use aquadest is then dried, is later; then dropped by lugol condensation (Gram B) 1-3 drip, made by hapusedly, hushed, later; then, cleaned and dried, is then dropped with acetate alcohol (Gram C) 1-3 drip is then made by hapused, hushed, and cleaned to use aquadest and dried, is later; then dropped by safranin (Gram D), made by hapusedly is later; then hushed, is then cleaned to use aquadest and dried, is afterwards perceived by below microscope with magnification $10 \mathrm{X}$.

\section{Growth test at Media of Waste Petroleum}

The isolate obtaint, is hereinafter analysed by ability in petroleum waste degradations, conducted by 15 liquid petroleum waste $\mathrm{mL}$ is PT. Chevron, Dumai, Riau in packing into 4 solder cup differ, then bacterium isolate which grow to be made by suspension. Isolate $A$ to suspention, isolate $B$ suspension, and $A+B$ mixture isolate suspension and positive control suspension of Pseudomonas sp, is successively dripped into petroleum waste media at A solder cup (cawan petri), B, $\mathrm{C}$, and $\mathrm{D}$, each incubased at temperature $37^{\circ} \mathrm{C}$ during 48 clock, and perceived by its growth.

\section{RESULT AND DISCUSIONS}

The data supporter of taken by is moment intake of spons sampel in Melawai Beach of Balikpapan presented in Tables 1.

Table 1. Condition Of territorial water dot Sampling of sampel code 1 at Melawai Beach of Balikpapan

\begin{tabular}{|l|c|}
\hline \multicolumn{1}{|c|}{ Parameter } & Assess Measurement \\
\hline Co-ordinate sampling & $\begin{array}{c}01^{0} 16.36^{\prime} 8^{\prime \prime} \mathrm{LS} \\
116^{0} 48.23^{\prime} 6^{\prime} \text { ' BT }\end{array}$ \\
\hline Temperature ( $\left.{ }^{\circ} \mathrm{C}\right)$ & 29 \\
\hline Salinity & $30 \% 0$ \\
\hline Ph & 7 \\
\hline Deepness of sampling & $2,70 \mathrm{~m}$ \\
\hline
\end{tabular}


There is found spons type at Melawai Beach of Balikpapan later on SP.1 sampel code is given; SP.2; SP.3; and SP.4.

Fourth physical characteristic of sponge of sampel type perceived direct is field, for the spons of Sp1 code: chocolate crem colour, long form and gang, owning spicula in the form of silicate and is fibrous of spongin. Sponge of Sp2 codes: fair purple, owning cavity and gang, silicate spicula with spongin fibre, spons of Sp3 code: green colour, domed form gang, spicula do not see, sharppointed back part, stiff harsh and also, while for the sponge of Sp4 code: easy brown, long form and disseminate, spicula in the form of calcite with spongin fibre

\subsection{Morphology sample of sponge}

2, following:

Result of fourth morphology analysis of sponge sampel presented in Table

Tables 2. Result Analysis Morphology sample of Sponge from Melawai Beach, Balikpapan

\begin{tabular}{|c|l|l|l|}
\hline SP & \multicolumn{1}{|c|}{ Species } & \multicolumn{1}{c|}{ Family } & \multicolumn{1}{c|}{ Inventor } \\
\hline 1 & Callyspongia sp & Callyspon-giidae & $\begin{array}{l}\text { Duchassaing Michelotti, } \\
1964\end{array}$ \\
\hline 2 & Coelocarteria singaporensis & Chalinidae & Carter, 1883 \\
\hline 3 & Callyspongia (Cladocalina) vaginalis & Callyspon-giidae & Lamarck, 1814 \\
\hline 4 & Haliclona (Haliclona) oculata & Chalinidae & Pallas, 1766 \\
\hline
\end{tabular}

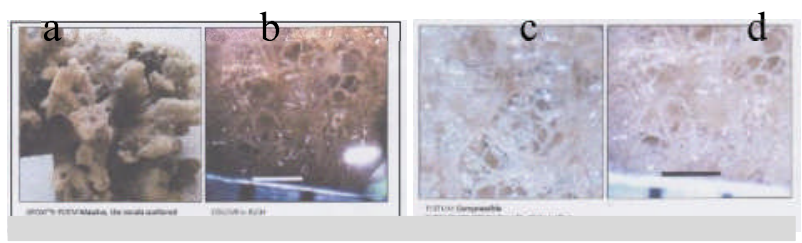

Figure 2. Result analysis morphology of sampel of sponge code sample is Sp1, namely: species of Callyspong ia sp., a) growth form massiva, raucous oscula as long as surface of sponge body; b) result of coloration with Etoh; c) tekstur result of compress; d) surface structure enlarged.

At the fourth of obtained sponge species from Melawai Beach of Balikpapan, after analysed morphology obtained by result there is 2 each set of relatives consist of 2 species, namely family of Callyspongiidae with species of Callyspongia (Cladocalina) Vaginalis and Callyspongia sp and also family of Chalinidae with species of Haliclona (Haliclona) Oculata and Coelocarteria singaporensis.

Bacterium of isolation symbions sponge done by just for Callyspongia sp species (sampel 1) from family of Callyspongiidae with reason that from is fourth of existing species only species of Callyspongia sp known to earn degradator of Polysiclic Aromatic Hydrocarbon (PAH).

\subsection{Isolation Bacterium Callyspongia sp symbion of sponge}

Isolation bacterium symbion at sponge of species of Callyspongia sp used media Sea Water Complit (SWC). Concentration thinning $10^{-1}$ until $10^{-5}$ done until 3 times series purification and each incubased during $1 \times 24$ clocks, is then conducted by macroscopic perception, that is colour, colony amount and form. perceived dominant colony that is white krem chromatic colony, big globularity with growth of meeting colony is later on named by A isolate and colony with 
chocolate white colour, jagged form is and length growth of colony disseminate, hereinafter named by isolate B. Perception of this morphology each seeing clear at thinning $10^{-2}, 10^{-3}$ and $10^{-4}$.

Result identifying of macroscopic of isolation sponge of Callyspongia sp obtained by two isolate. First Isolate with big globularity marking and crem chromatic- white is herein after referred to as isolate A and second isolate with jagged form marking, length, white chromatic is chocolate, herein after referred to as isolate B. Both this isolate is hereinafter purified by using ose needle and inscribed by at media of that marine-agar (MA 3). Purification of Isolate Bacterium Callyspongia $\mathrm{sp}$ which symbioning with sponge

\subsection{Purification of Isolate Bacterium Callyspongia sp symbion of sponge}

The result of perception obtained by isolate is hereinafter identifyed representing perception microscopicly to obtained isolate from the thinning by doing painting of gram. Breeding microbe colony is hereinafter purified by incised at medium Marine-agar to beheeling as which specific medium. Using by breeding purification technique is method of contiyu incision

Media growth commutation and purification conducted meant recuring to ascertain perity of isolate, so that give certainty that the isolate is which isolate with dominant.

Purification of isolate bacterium aim to to dissociate result of inoculasi which consist of many different bacterium colony of type is got by pure bacterium colony in each bacterium breeding. Colony of taken bacterium to be purified by colony of dominant. Purification by using cup method incises. Isolate A and obtained to be isolate $\mathrm{B}$, to be purified at media of Marine-Agar until thrice by recuring in each thinning aim to for the obtaining of really pure isolate and purification to four conducted by at media so that to be heeling, where both this isolate is identified can grow better at thinning $10^{-2}$ to $10^{-4}$.

\subsection{Identifycations and perception microsco-picly of isolate bacterium}

Table 3 Microscopic Examination with Coloration of Bacterium Gram Isolate A and Isolate B

\begin{tabular}{|l|l|l|}
\hline Perception & \multicolumn{1}{|c|}{ Isolate A } & \multicolumn{1}{c|}{ Isolate B } \\
\hline Colour & red purple & Violet \\
\hline Form & Bar & circular gang \\
\hline Colourant & dissolve colour & colour remain to \\
\hline Endospora & no spore & ill defined Spore \\
\hline Node & negative gram & positive gram \\
\hline
\end{tabular}

Hereinafter identify to be donewith microscopic examination conducted with painting of gram which aim to for the, giving of paint A (crystal violet) at positive gram of bacterium will be permeated and bound by part of external cell. Gift paint 
B (lugol) improved afinitas cordage of colour seent of vitamin by bacterium so that cordage of seen colour vitamin become is stronger.

At giving paint $\mathrm{C}$ (alcohol 96\%), positive gram bacterium of chromatic remain to be purple because violet crystal compound complex and laktofenol remain tied at cell wall. At addition paint D (safranin), the do not cause change of positive gram bacterium colour, because complex compound of violet crystal and iodium remain tied at cell wall.

The after passing giving process paint A (violet crystal), paint B (lugol), paint C (alcohol 96\%), and also paint D (safranin) in the reality isolate A of including into negative gram bacterium at microscope that is. thinning $10^{-2}$ to $10^{-4}$ got bacterium from all the is negativity gram bacterium maintaining safranin colour. This matter is caused by negative gram bacterium have lipid rate and high protein, [8]. Isolate B is positive gram bacterium, because at painting with safranin, do not cause change of colour in consequence of Crystal violet complex and iodium remain tied to cell wall.

\subsection{Test Growth of Isolate Bacterium the symbion of sponge}

\begin{tabular}{|c|c|c|c|c|}
\hline Treatment & Isolate A & Isolate B & $\begin{array}{c}\text { Isolate A } \\
+\mathbf{B}\end{array}$ & $\begin{array}{c}\text { Control } \\
\text { D }\end{array}$ \\
\hline $\begin{array}{l}\text { Media of petroleum } \\
\text { waste }\end{array}$ & - & - & - & - \\
\hline $\begin{array}{l}\text { Incubation } \\
1 \times 24 \text { clock }\end{array}$ & + & - & + & - \\
\hline $\begin{array}{l}\text { Incubation } \\
2 \times 24 \text { clock }\end{array}$ & + & + & ++ & - \\
\hline
\end{tabular}

\section{Boldness :}

$(-)$ - there is no growth of symbion bacterium

(+) - there is growth of symbion bacterium

The analysis growth of isolate bacterium at media of petroleum waste media, where suspension of isolate $A$, suspension isolate $B$, suspension isolat mixture $A+B$ and Pseudomonas sp bacterium suspention as positive control, each dripped by at petroleum waste in solder cup (cawan petri) and incubation at temperature $37^{\circ} \mathrm{C}$ during $2 \times 24$ hour. Obtained by result of isolate A, can grow at the media marked with the existence of solidity at solder cup, isolate B also can grow at petroleum waste media marked with formed its of transparent coat at surface of solder cup, while mix isolate $A+B$ also can grow at the media marked with the existence of transparent coat at surface of solder cup as well as formed by solidity.

This matter indicate that both isolate is the, namely isolate A and B isolate which is isolations from spons as symbion species Callyspongia sp can adapt to its growth media or environment, including according to environmental temperature and $\mathrm{pH}$ of growth. Bacterium Pseudomonas sp as positive control do not show growth at media of petroleum waste. This matter is caused by growth media at 
temperature $37^{\circ} \mathrm{C}$ and $\mathrm{pH} 7$ not such ideal environment for the growth of bacterium is Pseudomonas sp as control.

Is known that petroleum waste taken as media test growth of isolate can in the form of aliphatic hydrocarbon and aromatic indicating that one of the both types of the hydrocarbon or the two earning degradation by symbion bacterium isolate of spons Callyspongia sp coming from Melawai Beach of Balikpapan East Kalimantan, marked with the existence of growth of isolate after incubation during $2 \times 24$ clock. Result of this research give information that at least there is 3 variable which can influence growth of isolate at media of petroleum waste, that is; 1) temperature,

2) growth media of $\mathrm{pH}$ and hydrocarbon type which implied in media of petroleum waste. Research the thereby can be done of continu by take third this variable to know furthermore related to ability of the isolate in degradation of petroleum waste. That way also to both the isolate can be identified by bacterium species through method of Polymerase Chain Reaction (PCR) Real Time.

\section{CONCLUSIONS}

1. Result analysis of Melawai Beach of Balikpapan at spons of morphology, namely there is 2 set of relatives, that is first family is Callyspongiidae consist of 2 species namely Callyspongia (Cladocalina) Vaginalis and Callyspongia sp and both family is Chalinidae set of relatives and consist of 2 species namely Coelocarteria Sinagporensis and Haliclona (Haliclona) Oculata

2. The result identify macroscopic at isolation bacterium of symbion sponge at species Callyspongia sp obtained by 2 isolate. First of isolate A globularity, redish crem of colour and both isolate $\mathrm{B}$ is jagged, colour turn yellow is redish.

3. Identify microscopic for the isolate $\mathrm{A}$ is type bacterium of gram negative and isolate $\mathrm{B}$ is type positive gram bacterium isolate

4. The bacterium isolate $A$, isolate $B$ and mixture isolate $A+B$ can grow at media of petroleum waste, while positive control of Pseudomonas sp as pure bacterium suspension cannot grow.

\section{BIBLIOGRAPHY}

[1] Ahmad, F., 2012. Kandungan Senyawa Polisiklik Hidrokarbon (PAH) di Teluk Jakarta, Jurnal Ilmu Kelautan, vol 17(4):199-208

[2] Balba, M.T., N. Al-Awadhin and R.Al-Daher,. 1998. Bioremediation of oilcontaminated soil: microbiological methods for feasibility assessment and field evaluation. Journal Microbiological Methods,vol. 32: 155-164

[3] Carolyn R. Esposito, 2011. Site demonstration of The Dynaphorager Spong Technology, Risk Reduction Engineering Laboratory, USA, New Jersy

[4] Crawford, R.L., Crawford, D.L., 1996. Bioremediation principles and applications. Cambridge : Cambridge University Pr.

[5] EPA, (2008). Polyciclic Aromatic Compounds Category, United States Enviromental Protection Agency Office of Enviromental Information, Emergency Planning and Community for Reforting Toxic, Washington DC, EPA 260-B-01.03

[6] Friederich, A.B., H. Maerkert, T. Fendert, J. Hacker, P. Proksch and U. Hentschel, 1999. Microbial diversity in he marine sponge Aplysina 
cavernicola (formely Verongia cavernicola) analyzed by fluorescence in situ hybridization (FISH). Journal Mar. Biol. 134: 46 1-470

[7] Grihchenkov, V.G., R.T. Townsend, T.J. Mc Donald., R.L. Autenrieth, J.S., Bonner and A.M. Boronin., 2000. Degradation of petroleum hydrocarbons by facultative anaerobic bacteria under aerobic and anaerobic conditions. Journal Process Biochemistry, vol. 35: 889-896

[8] Hartati, 2012. Dasar-dasar Mikrobiologi Kesehatan. Nuha Medika. Surakarta

[9] Hooper, J.N,A., 1997. Guide to sponge collection and identification. Version Merch.

[10] Irianto, K. 2013. Mikrobiologi Medis. Alfabeta. Bandung

[11] Jayardana Trigunawan, 2006. Penilaian Terpadu Dampak Tumpahan Minyak Di Perairan Balikpapan : Studi Kasus Tumpahan Sludge Oil Dari Kapal Mt. panos, Tesis UI.

[12] Kim, T.K., Hewavitharana, A.K., Shaw, P.N., and Fuerst, J.A., 2006. Discovery of a new source of rifamycin antibiotics in marine sponge actinobacteria by phylogenic predictions, Journal Appl. Environ. Microbial., vol. 72:2118-2125

[13] Mahdiyah, D., Wahyudi, T. A., Mukti, H. B., 2012. Isolasi bakteri yang berasosiasi dengan spons Jaspis sp. penghasil Enzim Protease. Jurnal Bioscientiae, Januari 2012, vol. 9 (1) :1-7

[14] Marzuki, Ismail, 2014. Analysis of Heavy Metal sea Sediment from Melawai Beach of Balikpapan, East Kalimantan, Prosiding International Conference of the Indonesian Chemical Society, Unpatti, Ambon, 17-18 September 2014.

[15] Munifah, I., 2008. Sponge: Biota laut penghasil senyawa bioaktif yang potensial. Laboratorium Bioteknologi Kelautan Pusat Riset Pengolahan Produk dan Sosial-Ekonomi Kelautan dan Perikanan

[16] Munir, Erman, 2008. Pemanfaatan Mikroba dalam Bioremediasi, Pidato Pengukuhan Guru Besar, Repository, USU, Medan

[17] Murniasih. T., dan Rasyid, A., 2010. Potensi bakteri yang berasosiasi dengan spons asal Barrang Lompo-Makassar sebagai sumber bahan anti bakteri, Jurnal Oseanologi dan Limnologi, 2010, vol. 36 (3): 281-292

[18] Pichinoty, F., J.B. Waterbury, M. Mandel and J. Asselineau., (1986). Bacillus gordonae sp. nov., Une nouvelle espêce apparte - nantt au second groupe morphologique degradant divers compose aromatiques. Ann. Inst. Pasteur, vol. 137 A: 65-78.

[19] Puspandari, Dyah. 2012. Biodegradasi Dengan Isolat Bakteri Indigenous Limbah Minyak Bumi Di Pantai Batakan Balikpapan, Thesis

[20] Syakti, D. A., Yani, M., Hidayati, V.N., Siregar, S.A. Doumeng, P., I.M. Sudiana, M., 2013. The Bioremediation potential of hydrocarbonoclastic bacteria isolated from a Mangrove Contaminated by Petroleum Hydrocarbons on the Cilacap Coast, Indonesia. Journal Bioremediation, vol. 17(1):11-20, ISSN: 1088-9868 online. DOI: 10.1080. 731446

[21] Udofia and Ekpo, 2008. Rate of biodegradation of crude oil by microorganism isolate from oil sludge environment. African journal of biotechnology, vol.7 (24)

[22] Venkateswara, J.R.et al., 2009. The Use of Marine Sponge, Haliclona Tenuiramosa as Bioindicator to Monitor Heavy Metal Pollution in The Coasts of Gulf Mannar, India. Journal Environ Monit Assess, Springer, 156: 451-459 
[23] Wahl, M., Jensen, P.R., Fenical, W., (1994). Chemical control of bacterial epibiosis on Ascidians. Journal Mar. Ecol. Prog. Ser., vol. 110:45-57

[24] Zarilla, K.A. and J.J. Perry. (1987). Bacillus thermoleovorans, sp. nov., a species of obligately thermophilic hydrocarbon utilizing endospore-forming bacteria. Journal Systematic and Applied Microbio-logy, vol. 9: 247-255 